\title{
Acontecimientos, grupos y mentores: sobre agentes de politización y entradas múltiples a la política en Argentina
}

Mariana Gené1

\section{Resumen}

Este artículo analiza las entradas en política de las elites del Ministerio del Interior en Argentina, y los aprendizajes provistos por aquellos procesos múltiples de politización. Apoyado en entrevistas en profundidad, material de archivo, registros periodísticos y bibliografía específica, el trabajo busca echar luz sobre el carácter central de los acontecimientos históricos, los grupos de militancia y los mentores o "padrinos" en tales caminos de ingreso. En primer lugar, reflexionamos sobre el rol de los sucesos políticos entendidos como hitos de politización, que alimentan luego una disputa por su interpretación y apropiación. Luego, nos referimos al carácter múltiple de los grupos de militancia y de los saberes teóricos y prácticos allí cosechados. Finalmente, nos detenemos en el papel que cumplen los padrinos a la hora de facilitar experiencias y contactos, rudimentos fundamentales para el oficio de político.

Palabras-clave: Socialización política. Acontecimientos. Militancia. Mentores.

\section{Introducción}

Las vías de "entrada en política" han retenido la atención de diversos estudiosos en sociología política (OFFERLÉ, 2017; LÉVÊQUE, 1996; OFFERLÉ; SAWICKI, 1996), buscando comprender los rasgos y las

Mariana Gené es Licenciada en Sociología (UBA), Doctora en Ciencias Sociales por la UBA y en Sociología Politica por la Ecole des Hautes Etudes en Sciences Sociales de Paris. Es investigadora asistente del CONICET con sede el Instituto de Altos Estudios Sociales de la Universidad Nacional de San Martín (IDAES-UNSAM) y docente de la Universidad de Buenos Aires, la Universidad Nacional de General Sarmiento y la Universidad Nacional de San Martín. e-mail: mariana.gene@yahoo.com.ar 
particularidades de una carrera singular, cuyos canales y capitales de ingreso fueron variando en la historia larga de la profesionalización política, es decir, “[...] de la aparición, a menudo concomitante de la estabilización del sufragio 'universal' (primero masculino), de una categoría de agentes especializados y profesionalizados en la conquista y el ejercicio de un tipo particular de poder, el poder político" (OFFERLÉ, 2011, p. 85).

En estas páginas nos referiremos a los procesos de politización de un tipo particular de personal político en Argentina: los ocupantes de las primeras y segundas líneas del Ministerio del Interior, desde la vuelta de la democracia hasta 2007. Nos enfocamos en esta cartera por tratarse del ministerio eminentemente "político" del gabinete nacional, tanto por sus principales tareas (que incluyen la articulación con las provincias y distintos actores políticos subnacionales, la negociación de leyes fundamentales para el Poder Ejecutivo, la organización de las elecciones y los proyectos de reforma política, la comunicación y justificación de la agenda del gobierno nacional y la puesta en marcha de distintas estrategias para garantizar la gobernabilidad) como por sus interlocutores privilegiados (gobernadores y ministros provinciales, intendentes y sus colaboradores, senadores y diputados, líderes partidarios y referentes políticos, además de periodistas y actores sectoriales relevantes). Así, nos ocupamos de profesionales de la política altamente experimentados, pero indagamos en sus primeros aprendizajes, cuando todavía no existía un dominio de ese saber-hacer que habría de emparentarlos y enfrentarlos.

En particular, nos referimos a tres aspectos fundamentales de esos procesos múltiples de entrada en política. Primero, a los grandes acontecimientos históricos que actuaron como agentes politizadores y renovaron al personal político de los dos grandes partidos mayoritarios en Argentina ${ }^{2}$. Mostraremos la importancia de tales eventos durante la juventud, el peso que tuvieron

2 Se trata de la Unión Cívica Radical (UCR), a la que nos referiremos también como radicalismo, y del Partido Justicialista (PJ), al que nos referiremos también como peronismo o justicialismo. Estos dos partidos se alternaron en el poder desde la instauración del sufragio universal a principios del siglo XX hasta 2015 (en rigor de verdad, desde diciembre de 2015 el radicalismo ocupa también el poder mediante la coalición "Cambiemos", pero por primera vez es el socio minoritario en el Poder Ejecutivo, que es conducido por el lider del PRO, Mauricio Macri). Las presidencias en el período analizado (1983-2007) fueron las siguientes: Raúl Alfonsin (UCR, 1983-1989), Carlos Menem (PJ, 1989-1999), Fernando De la Rúa (UCR-Alianza, 1999-200I), Eduardo Duhalde (PJ, 2002-2003) y Néstor Kirchner (PJ, 2003-2007). 
sobre determinadas generaciones políticas y el carácter a la vez experiencial y retrospectivo del sentido acordado a aquellos períodos intensos. Nos referiremos, además, al modo en que reforzaron o trastocaron ciertas identidades partidarias, y contribuyeron a conformar una determinada concepción de la política entre sus miembros. En segundo lugar, volveremos sobre los grupos y redes de pertenencia que canalizaron aquellos ingresos. En ellos, se acumularían recursos y experiencias, se incorporarían códigos y repertorios de acción frente a situaciones típicas del trabajo político, y se cosecharían contactos y conocimientos que serían vitales para su desempeño posterior. Por último, nos detendremos en el lugar fundamental de los padrinos y mentores en el ámbito político, en su carácter plural y en los aprendizajes prácticos que promueven en sus seguidores. Sostendremos, entonces, que su incidencia importa tanto en las entradas al mundo de la política como en el desarrollo ulterior de estos dirigentes.

Apoyados en entrevistas en profundidad ${ }^{3}$, trabajo de archivo y relevamientos de prensa, mostraremos el carácter polifacético de estos procesos de politización, y los entramados sociales e históricos que los moldearon.

\section{Hitos de politización}

La politización presenta muchas veces la forma de una irrupción histórica. En el caso de las elites del Ministerio del Interior argentino, sus entradas en política se vieron mayoritariamente enmarcadas por grandes acontecimientos ocurridos durante su juventud. Algunos de estos dirigentes provenían ya de familias fuertemente politizadas - con padres, tíos o abuelos que habían ocupado cargos electivos- y por lo tanto habían entablado una relación asidua con ese mundo desde su más tierna infancia. Para otros, la política se convirtió en un polo de entusiasmo y compromiso a partir del colegio secundario y la universidad. Pero la experiencia activa de la militancia propiamente dicha se inició para la gran mayoría en las agrupaciones estudiantiles de la secundaria - muchas veces en los colegios públicos más prestigiosos de la Capital Federal,

3 Realizamos 40 entrevistas semi-estructuradas entre mayo de 2009 y julio de 2012. De ellas, 35 tuvieron lugar entre el personal político de mayor jerarquía del Ministerio (ex ministros, secretarios y subsecretarios de Estado), y 5 se realizaron a miembros de su burocracia, a fin de complementar la perspectiva analizada y completar datos inaccesibles por otros medios. 
el Colegio Nacional de Buenos Aires o el Carlos Pellegrini ${ }^{4}$, y del interior del país- o, más comúnmente aún, en la época universitaria.

$\mathrm{Si}$ aquellos espacios fueron propicios para iniciar una participación temprana en política, ciertos eventos históricos fueron determinantes para desencadenar ese acercamiento. Como ha mostrado extensamente Ihl (2002), la importancia de los acontecimientos históricos en la socialización política durante la juventud suele ser mayúscula. Para el autor, de hecho, ciertos eventos son agentes socializadores en sí mismos. Aun teniendo en cuenta el carácter lábil de la noción de acontecimiento político - "su plasticidad simbólica, su elasticidad histórica, la pregnancia de su dimensión subjetiva” (IHL, 2002, p. 138) -, la experiencia de tales situaciones provee oportunidades de socialización de diversas maneras: por medio del contacto directo con una dinámica colectiva - hecha de movilización y protesta, de participación electoral o acción militante -, por una exposición al flujo de información que proveen los medios sobre tales situaciones - una campańa de prensa ligada a un escándalo político, un duelo televisado al final de una campaña electoral -, por medio de las interacciones que activan esos procesos - discusiones familiares, debates en el lugar de trabajo o estudio, etc. - (IHL, 2002, p. 138-139). Se trata de toda una serie de mediaciones que contribuyen a traducir y estabilizar un acontecimiento político, con los actores que se movilizan durante y después de esa particular dinámica.

En el caso que nos ocupa, las experiencias de entrada en política se vieron marcadas por períodos históricos intensos, signados por recurrentes interrupciones del orden democrático y por una enorme politización de la sociedad argentina. Así, tanto para los políticos radicales como para los peronistas, ciertos sucesos históricos marcaron grandes oleadas de ingreso a la participación política (y lo hicieron de diferente manera). Durante el siglo XX el régimen democrático se vio sucesivamente interrumpido en Argentina y la inestabilidad institucional fue crónica. Pero lejos de sofocar las ansias de actividad política, los repetidos golpes de Estado y la proscripción de los partidos contribuyeron a alimentarlas e intensificarlas. En cada caso, el

4 Colegios dependientes la Universidad de Buenos Aires, gozan de gran prestigio y tienen una amplia tradición en la formación de elites meritocráticas y líderes políticos. Sobre el CNBA, consultar: Méndez, 2013. 
golpe hacia un gobierno, la prohibición de un partido político, la expectativa del retorno democrático, los grandes movimientos en contra de ajustes económicos o del cercenamiento de derechos obreros alumbraron nuevos canales de participación colectiva.

Para la camada de políticos radicales de mayor edad, la Revolución Libertadora y el golpe de Estado contra el gobierno de Arturo Illia constituyeron hitos de insoslayable importancia. El primero de ellos - la auto-denominada "revolución libertadora" - fue el golpe cívico-militar que derrocó a Juan Domingo Perón en 1955 y se mantuvo en el poder durante poco más de dos años, al cabo de los cuales se celebraron elecciones con el Partido Justicialista proscripto. El segundo hito fue otro golpe de Estado, pero esta vez contra un presidente radical, Arturo Illia, que también había llegado al gobierno mediante elecciones en las que las Fuerzas Armadas habían prohibido la participación del peronismo. Illia gobernaría de 1963 a 1966, fecha en que sería derrocado por el gobierno de facto de Juan Carlos Onganía. Muchos de los dirigentes que se desempeñarían luego de la vuelta de la democracia en 1983 en el gobierno de Raúl Alfonsín evocan esos acontecimientos como grandes mojones en su politización. La Unión Cívica Radical tenía ya una larga tradición en la ampliación de derechos y del campo político, había contribuido a fabricar lentamente a los políticos profesionales (FERRARI, 2008) y erigido todo un ideario basado en el republicanismo, el igualitarismo y el liberalismo (ROMERO, 1992 [1956]; ROCK, 1992 [1977]). La memoria del primer peronismo como un gobierno autoritario y antidemocrático, en el que los opositores eran perseguidos y el aparato del Estado se utilizaba en favor de la propaganda política, contribuye a explicar su justificación casi automática del derrocamiento de Perón:

"Yo era estudiante en 1955, había caido Perón con la Libertadora, la denominada Revolución Libertadora y bueno, me afilié al partido porque cumpli los 18 años [...] Entonces, los del Centro [de estudiantes del Colegio Nacional Buenos Aires], entre ellos estaba yo, ya estaba en $6^{\circ}$ año, tomamos el Colegio en el patio, paramos las clases. Entonces, sacamos los cuadros de Perón y de Evita que había en la vice-rectoría [...] me acuerdo que el vicerrector era muy peronista, era profesor nuestro de Higiene asi que nos conocía a todos. Bueno, entramos al despacho, el tipo se puso muy nervioso, y le dijimos 'Habiendo renunciado el dictador venimos a remover los cuadros'. Sacamos los cuadros, tomamos el colegio en el patio de $6^{\circ}$ año, pusimos los cuadros - que eran varios - diseminados por el piso y cada 
delegado del Centro, de cada año, de cada división, salía y los pisaba en presencia del vicerrector." (Información verbal - GENÉ, 2009)5.

Esa mitad del siglo XX fue particularmente álgida, con el peronismo proscripto por 18 ańos $^{6}$ y una recurrente interrupción del (precario) orden constitucional por parte de las Fuerzas Armadas. Así, los presidentes radicales Arturo Frondizi y Arturo Illia también durarían poco tiempo en sus cargos (casi cuatro ańos el primero y algo menos de tres años el segundo), asediados por los militares, por un lado, y por la presión de las bases peronistas, por el otro.

Estos tiempos fueron de gran participación para los radicales y devinieron en momentos clave de su ingreso a la política y su modo de concebirla: las distintas ramas del partido mantenían relaciones de mayor o menor proximidad con los militares y con el peronismo, que se convertiría en la gran alteridad en relación a la cual urgía posicionarse. En efecto, el clivaje peronismo/ antiperonismo pasó a organizar gran parte de la historia argentina, y fracturó a la Unión Cívica Radical: en 1957 el partido se dividió en la Unión Cívica Radical Intransigente (UCRI), liderada por Frondizi y dispuesta a buscar una forma de conciliación o inclusión del PJ en el campo político argentino, y la Unión Cívica Radical del Pueblo (UCRP), liderada por Ricardo Balbín y el ala del radicalismo más partidaria de "desperonizar" el país. Con sus matices y énfasis diferentes, no obstante, aquellos eventos socializadores hicieron que para unos $\mathrm{y}$ otros pertenecer al radicalismo significaba pertenecer al polo democrático y republicano del campo político.

"En realidad la decisión que yo tomo y el inicio de la militancia más activa es por un hecho que podriamos calificar como negativo, que fue el golpe contra Illia que se produjo en el año 1966. Yo era muy joven, pues tenía 15 años, pero me produjo un impacto tan negativo su derrocamiento, la injuria y la calumnia que padecía su gobierno, que eso me llevó a, a involucrarme mucho más directamente en la militancia política, toda vez que yo ingreso en la facultad a los 16 años. Entonces ingresé muy muy joven, casi inmediatamente después del golpe que derrocó a Arturo Illia y ya empecé una militancia muy activa que no ha parado" (Información verbal - Gené, 2009) ${ }^{7}$

5 Secretario de Interior durante la Presidencia de Alfonsin, UCR. Entrevista con la autora el 19 mayo de 2009.

6 En 1973, el PJ volvería al poder por medio de elecciones libres, pero tres años más tarde, con el golpe de 1976. se iniciaría la dictadura más larga y sangrienta de la historia argentina.

7 Ministro del Interior durante la Presidencia de De la Rúa-, UCR-Alianza. Entrevista con la autora el 3 septiembre de 2009. 
Por su parte, para los peronistas hubo determinados eventos especialmente significativos que marcarían su conexión con el partido ${ }^{8}$. El Cordobazo, movimiento obrero y estudiantil que estalló en mayo de 1969, representó un suceso de innumerables consecuencias, entre las que se contó un fuerte ingreso de jóvenes a la militancia política. Se trató de un levantamiento popular que tuvo lugar en uno de los principales centros industriales del país, la provincia de Córdoba, y fue gestándose en sucesivas asambleas sindicales y huelgas en contra de la política económica y las medidas anti-sindicales de Onganía y su ministro de Economía, Adalbert Krieger Vasena. El levantamiento estalló en la ciudad y sus periferias tras contarse la primera víctima fatal de la represión, y las movilizaciones y barricadas generaron apoyos masivos de múltiples sectores, desbordando el poder de la policía para contrarrestarlos (O’DONNELL, 1996 [1982]). A ello siguieron masivas explosiones en Rosario, Córdoba y Buenos Aires. Los distintos alzamientos en centros urbanos redoblaron las tensiones que había acumulado el gobierno autoritario, que buscaba obtener la "paz social” por medio de una represión cada vez más sistemática (O’DONNELL, 1996 [1982]), p. 258 y ss.). En esta época en la que ninguna fórmula política fue capaz de contener los conflictos que atravesaban a la sociedad (DE RIZ, 2000), frente a la represión militar y la ilegalidad de todas las manifestaciones populares, proliferaron los grupos políticos dentro del peronismo y comenzaron a gestarse las organizaciones armadas que verían la luz a fines de $1970^{\circ}$. Uno de los entrevistados sentenciaría, al respecto, “¡fueron los militares los que nos metieron en política!":

"Los muchachos fueron tan finos que mataron a Pampillón 10, cuando yo entraba a primer año del colegio secundario; entonces ahí fui a mi primera manifestación porque lo mataron a Pampillón. Y ahí me llevó el río. O sea, me enganché, tenía los mensajes de Perón de

8 Vale decir que, como los dirigentes políticos que estudiamos son aquellos que ocuparon los peldaños más altos del Ministerio del Interior en el periodo 1983-2007, nuestra muestra hace que para los peronistas (recién en el poder a partir del gobierno de Carlos Menem, durante 1989-1999) no hubiera una camada socializada en política con la irrupción del peronismo en 1945.

9 En junio de ese año irrumpieron los Montoneros con el secuestro y asesinato del ex dictador Pedro Eugenio Aramburu. Unos meses más tarde comenzaron a funcionar las Fuerzas Armadas Peronistas (FAP) y las Fuerzas Armadas Revolucionarias (FAR), que se fusionarian con Montoneros; asi como el Ejército Revolucionario del Pueblo (ERP), de extracción marxista. En el próximo apartado volvemos sobre la importancia de estos grupos para la socialización política de los dirigentes estudiados.

10 Santiago Pampillón era un militante estudiantil de la Franja Morada en la Universidad Nacional de Córdoba. Fue asesinado por la policía durante la dictadura de Onganía, en septiembre de 1966, en el marco de la represión a una huelga masiva en oposición a la intervención de las universidades públicas, iniciada ese mismo año en "la noche de los bastones largos". 
Madrid, que los veían en cinta con unos cosos grandes asi, era una cosa completamente épica [...]. Después de eso lo metieron preso a Coriall. O sea, era muy difícil que no te conmoviera. Porque era cercano, inmediato, a pares tuyos: estos eran estudiantes, hijos de clase media trabajadora, que los mataban porque estaban en desacuerdo con el gobierno. No sé, para ser indiferente tenías que ser muy especial. En mi generación, en mi generación no hay que preguntarles ¿cómo fue que vos te metiste en política? [tono de alegremente despreocupado] Ahora, si vos te metés en política te van a preguntar: ‘ $Y$ vos cómo te metés en política??' Pero en mi generación tenés que preguntarle ‘Y vos cómo no te metiste?'. Porque ¿me entendés? Estaba muy cerca. Estaba muy cerca”. (Información verbal - Gené, 2009) ${ }^{12}$.

Efectivamente, bajo un régimen que buscaba eludirla, la política estaba omnipresente. “ $¿ Y$ vos cómo no te metiste?" era un interrogante posible para los jóvenes de clases medias y centros urbanos que poblaban las facultades. La participación para ellos no era atípica sino, antes bien, altamente probable. Con Perón en el exilio, su imagen no hacía más que agrandarse, al tiempo que crecían las apuestas para apropiarse su interpretación correcta tanto en la izquierda como en la derecha del Partido Justicialista. Muchos de los que ocuparían luego las primeras líneas del Ministerio del Interior vuelven sobre ese carácter presuntamente ineludible del compromiso político. La presencia del peronismo (y de su contraparte, el anti-peronismo) era fuerte en manifestaciones populares muy disímiles, en el contexto de un alto nivel de politización en toda la sociedad:

Yo empecé a militar muy joven, tenía 14 años. [...] Era impensado que un pibe de unos pocos años se pusiera a militar en política, sin embargo era mucha la mística, mucha mistica del momento, ¿no? Se suponía que Juan Perón iba a venir aqui a la Argentina en algún momento y bueno, yo soy fanático de Quilmes, y la hinchada gritaba - en los "70 sería más o menos - 'Lanusse 13, Lanusse, prestá mucha atención: Quilmes a primera y la vuelta de Perón”'. (Información verbal - Gené, 2009) ${ }^{14}$.

$1 /$ Rogelio Coria, dirigente gremial de la construcción, sería, junto con Vandor, uno de los sindicalistas partidarios de construir un "peronismo sin Perón". A partir de 1967 comienza a desplazarse hacia la derecha del arco político y negocia con el régimen de Onganía medidas que perjudicaban a los afiliados de la UOCRA, como la eliminación de la indemnización por despido (Clarín, 29/06/2000). Acusado de traidor, fue asesinado por Montoneros en 1974.

12 Ministro del Interior durante la Presidencia de Menem, PJ. Entrevista con la autora el 22 octubre de 2009.

13 Presidente de facto entre marzo de 1971 y mayo de 1975. Durante esos años el peronismo estuvo proscripto y su lider fuera del pais por orden militar. Su vuelta, en 1973, sería sangrienta ya que ambos extremos del peronismo se enfrentarían el día de su llegada al aeropuerto de Ezeiza.

14 Ministro del Interior durante la Presidencia de Kirchner, PJ. Entrevista con la autora el 12 noviembre de 2009. 
Si para los radicales más añosos, cuyas entradas en política se iniciaron en el marco de los golpes de Estado de 1955, 1962 o 1966, la pertenencia a la UCR suponía el valor del republicanismo y la democracia; para los peronistas politizados durante los ańos sesenta y los tempranos setenta, la pertenencia al PJ suponía el valor de la resistencia - suscitada por la represión y la proscripción - y del carácter nacional y popular de su movimiento.

Hacia el final de la dictadura, una última gran oleada de entrada en política estuvo constituida, para los radicales, por la renovación emprendida en el seno de la UCR por la figura de Raúl Alfonsín. El denominado "tercer movimiento histórico" tuvo para ellos la virtud de sacudir al partido de su sesgo conservador y profundamente antiperonista para darle un nuevo programa, más popular y capaz de interpelar a amplios sectores de la sociedad. Esta gran transformación que lograría nada menos que vencer al peronismo en elecciones abiertas y sin censuras por primera vez en la historia, fue la puerta de entrada para una amplia camada de dirigentes radicales:

Mi familia y mi padre estuvo siempre afiliado y cercano a la Unión Cívica Radical, pero allá por la década del 70, cuando yo tenía 13 o 14 años, veía al radicalismo como demasiado poco revolucionario [...]. Cuando tenía 16 años vino el golpe de marzo del 76; yo tenía a mi hermana estudiando en Córdoba y a través de ella empecé a leer visiones distintas, como Las venas abiertas de América Latina. Y un día trae a mi casa La cuestión argentina, un libro que Raúl Alfonsin había escrito y editado en España. Debe haber sido el año 80, 81 [...]. Después ya había pasado en la universidad el fracaso de Malvinas y la locura de Malvinas, y bueno, yo ya había leído este libro, y cuando lo lei a Raúl Alfonsin me sentí muy identificado con su pensamiento, con su visión, con su ideología. (Información verbal - Gené, 2009) ${ }^{15}$.

El hecho de que Alfonsín hubiera sido uno de los pocos políticos argentinos que se opuso abiertamente a la participación en la guerra de Malvinas promovió, en efecto, la adhesión de futuros cuadros que no empatizaban con el clima triunfalista que acompañaba a la gesta propuesta por la dictadura militar, o que tras la derrota bélica resignificaron su postura ante la guerra. Tal como afirma Ihl (2002, p. 139):

15 Secretario de Provincias durante la Presidencia de De la Rúa, UCR-Alianza. Entrevista con la autora el 17 septiembre de 2009. 
La naturaleza de un acontecimiento se debe antes que nada a su tratamiento: a las confrontaciones de lo que podemos llamar agentes de ejemplaridad (periodistas, historiadores, investigadores/ analistas). Su rol es central en el control de las 'figuras' y los 'relatos' a través de los cuales los grupos sociales y las comunidades políticas se representan a sí mismos.

La oposición de Alfonsín a la guerra de Malvinas, cuya estrepitosa derrota sellaría el fin del gobierno militar, es un buen ejemplo del modo en que los acontecimientos políticos y su naturaleza siguen retrabajándose y resignificándose a través de los años. En un inicio, en medio del fervor popular, el propio Alfonsín había tenido palabras de apoyo hacia la iniciativa bélica, afirmando "el hecho tiene el respaldo de todo el país. Es una reivindicación histórica que tiene el asentimiento y la unanimidad de todos los argentinos", "el episodio pone de manifiesto que los argentinos sabemos unirnos para la defensa de las grandes causas"16 (NOVARO; PALERMO, 2006 [2003], p. 439). Pero de la mano de sus asesores Dante Caputo, Jorge Roulet y Jorge Sábato, ese diagnóstico fue cambiando hasta convertirse en uno de los pocos referentes que manifestó explícitamente su rechazo (NOVARO; PALERMO, 2006 [2003], p. 440). La retórica que luego iba a acompañar ese acontecimiento sería la del líder político que estaba, en cierto sentido, adelantado a su tiempo, el que se distinguía de los demás en su verdadera vocación democrática y en su decisión de no acompañar "aventuras" militares. Por cierto, los acontecimientos políticos no están hechos solamente de las declaraciones o acciones de un líder, de las movilizaciones de actores y sus efectos inmediatos, sino también de todo el trabajo de interpretación y puesta en sentido que ocurre después. Para la narración del radicalismo, este gesto marcaría el inicio de un cambio rotundo y exitosos en la capacidad del partido de reinventarse y de interpelar a nuevos sectores de la sociedad que antes le eran esquivos. En este sentido, la campańa presidencial de Alfonsín marcaría además un antes y un después en la capacidad de convocatoria del partido:

Y empieza el quilombo de Malvinas, yo tendría 14015 años [...]. Me hice ultra alfonsinista ahi porque Alfonsin fue el único político argentino que no avaló -me acuerdo que hicieron un viaje muchos políticos, Balbín, estaba Oscar Alende también en esa época y dejó de gustarme cuando lo ví yendo en ese barco [...]. Y Alfonsin era el único que estaba en contra.

16 Convicción, 04/04/1982, citado en Novaro y Palermo (2006 [2003]). 
Entonces, empieza todo ese proceso de la Guerra de Malvinas que de alguna manera fue el derrumbe de la dictadura [...]. (Información verbal - Gené, 2012)17.

Todavía con prohibición de la actividad política en julio del año '82, ya producida la derrota militar en Malvinas, organizamos un acto en la Federación de Box. E hicimos una reunión de la Coordinadora en el estudio de Roque Carranza, y me acuerdo que haciamos un punteo para saber si ibamos a estar en condiciones de llenarla: cuántos venían de La Plata, y cuántos venían de la Capital, etc. Y era tan fuerte el impacto que había producido la posición nuestra, y en particular la de Alfonsín, contra la guerra de Malvinas que cuando las columnas organizadas llegaron, jla Federación de Box ya estaba llena! ja pesar de la prohibición política! Y eso fue casi como una bola de nieve: a partir de ahi fue un proceso de crecimiento espectacular. (Información verbal - Gené, 2012) ${ }^{18}$.

Esas vivencias intensas y el entusiasmo generalizado que despertó el alfonsinismo en la "primavera democrática" hizo que, para esa generación de radicales, la UCR volviera a ser sinónimo de democracia (entre otras cosas, Alfonsín leía el preámbulo de la Constitución en su campańa, reivindicando el valor de la ley y del estado de derecho tras siete ańos de dictadura), pero esta vez sin el componente visceralmente anti-peronista que había cundido entre las generaciones mayores de dirigentes y militantes. Otra de las consecuencias de aquella novedad impulsada por la figura de Alfonsín sería que también el peronismo estaría obligado a renovarse. Tras perder las elecciones presidenciales en la reapertura democrática, el PJ, acusado de pacto militarsindical y de prácticas violentas y autoritarias, comenzaría a gestar en su seno a la Renovación peronista ${ }^{19}$.

En todo caso, lo que es común a la mayor parte de los dirigentes del ministerio - y a muchos otros - es que su incursión en política se inició desde muy temprano, atravesada por eventos decisivos y enmarcada en

17 Subsecretario de Interior y Secretario de Asuntos Políticos durante la Presidencia de De la Rúa, UCR-Alianza. Entrevistas con la autora en 17 de febrero de 2012.

18 Ministro del Interior durante la Presidencia de De la Rúa, UCR-Alianza. Entrevista con la autora el 3 septiembre de 2009.

19 Fracción interna del peronismo fundada en 1983, tras la primera derrota de este partido en elecciones abiertas y sin proscripción. Se trataba de un a la de dirigentes jóvenes que se oponían a la dirigencia ortodoxa y sindical del partido proponiendo reformulaciones doctrinarias. Dirigidos por Antonio Cafiero, se enfrentaron a Carlos Menem en internas para la presidencia en 1988 y fueron derrotados. Sobre "la Renovación", consultar Aboy Carlés, 1996; Altamirano, 2004. 
coyunturas intensas de politización. La política se presenta entonces como una irrupción ligada a los grandes problemas de una época y a sus referentes históricos, como una práctica colectiva que sólo más tarde, y de a poco, iría volviéndose una profesión. Aquellos acontecimientos marcaron a generaciones enteras, generando olas de politización en distintos sectores de la sociedad, e imprimiendo en los participantes cierta concepción de la política y del lugar ocupado por sus respectivos partidos. Lejos de un efecto automático, aquellos eventos se inscriben "en el tiempo enredado de las representaciones y las prácticas” (IHL, 2002, p. 142), es decir, en la experiencia misma que los individuos tuvieron de ellos, y en el análisis retrospectivo que contribuiría a redefinirlos y dotarlos de sentido.

\section{Grupos plurales de socialización política}

Si los períodos históricos y los grandes acontecimientos políticos o culturales que los jalonan son un factor determinante para comprender procesos de politización de ciertas generaciones, los grupos y fracciones al interior de los partidos políticos contribuyen a cualificarlos y a rastrear aprendizajes y equipamientos que serían decisivos luego para sus carreras.

Centrar la atención en los caminos de entrada a la política y los procesos de aprendizaje de la peculiar profesión de político contribuye a comprender la particularidad de una práctica en la que la educación formal no reviste tanta importancia y en la que el entre-soi, la confianza y la habilidad para la negociación son determinantes.

En este sentido, el interés por la socialización no supone que en ella resida una suerte de molde de transmisión automático, capaz de explicar sin fallas las posiciones tomadas más adelante por los actores. Desde los análisis clásicos de Emile Durkheim sobre la socialización a través de la educación, se entiende por socialización al proceso por el cual la sociedad forma y transforma a los individuos, promoviendo la interiorización de valores, disposiciones y modos de actuar. Pero, como se argumentaría más tarde, la socialización no constituye un mecanismo de transmisión homogéneo, limitado a una etapa de la vida y necesariamente coherente, sino que existen una pluralidad de procesos de socialización, de carácter continuo y cuya variación es amplia (DUBET, 1994; LAHIRE, 2011 [2001]). En este sentido, "abrir la caja negra" 
de la socialización supone no evocar un mecanismo unívoco sino atender a procesos que tienen lugar en instancias múltiples (familia, escuela, grupos de pares, instituciones culturales, religiosas, políticas, etc.) y observar sus efectos.

Al estudiar las trayectorias políticas de las elites del Ministerio del Interior argentino, vemos, por un lado, tendencias particularmente marcadas: la enorme mayoría tiene un vínculo con la política partidaria entablado en la temprana juventud, suscitado por grandes procesos históricos que, como vimos, interpelaron a la sociedad argentina, produjeron grandes transformaciones históricas y renovaron al personal político. Estos caminos de entrada nos hablan de un grupo fuertemente politizado desde muy temprano, con trayectorias iniciadas en momentos bisagra de la historia argentina, en asociación con figuras decisivas y grandes movimientos de masas (cf. Cuadro 1). Se trata además de políticos altamente profesionalizados, con largas carreras, hechas de cargos partidarios y posiciones en el Estado ocupadas por medio de votos y de puestos de designación política. En este sentido, tal como hemos mostrado (GENÉ, 2014), salvo rarísimas excepciones, en este ministerio no hay outsiders o intrusos.

En lo que respecta al carácter disímil de los itinerarios recorridos por los actores, un análisis de sus espacios iniciales de militancia da cuenta de los acervos intelectuales y repertorios de prácticas heterogéneos de los que se nutrieron. Aquello que los une es elocuente: todos los ministros menos dos comenzaron su militancia con 20 ańos o menos. No obstante, esas experiencias fueron diferentes entre sí: las organizaciones de la izquierda y la derecha peronista, las fracciones más conservadoras o las más renovadoras del partido radical, la lucha armada y la oposición a la misma fueron algunos de los clivajes que los encontraron en caminos enfrentados. 


\begin{tabular}{|c|c|c|c|c|c|c|c|c|}
\hline 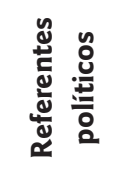 & 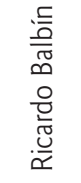 & $\frac{\sqrt{\frac{5}{n}}}{\frac{D}{0}}$ & 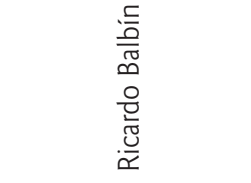 & 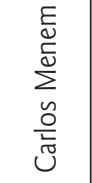 & ' & ' & 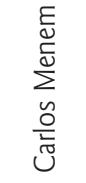 & 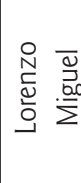 \\
\hline 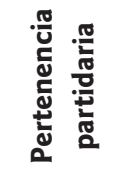 & $\stackrel{\widetilde{U}}{\mathrm{U}}$ & $\stackrel{\widetilde{U}}{\unlhd}$ & $\stackrel{\widetilde{U}}{\mathrm{U}}$ & $\bar{\alpha}$ & $\bar{\alpha}$ & $\bar{\alpha}$ & $\bar{\alpha}$ & $\bar{a}$ \\
\hline 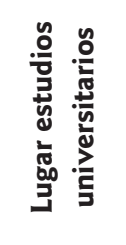 & 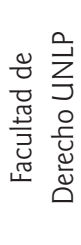 & 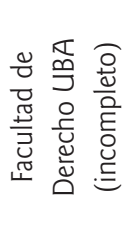 & 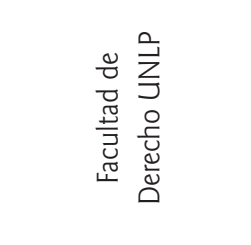 & 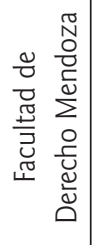 & 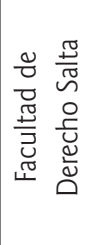 & 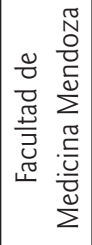 & 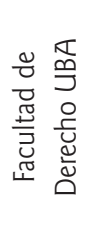 & 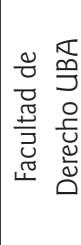 \\
\hline 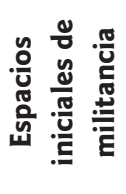 & 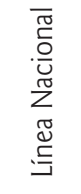 & $\underline{Z}$ & 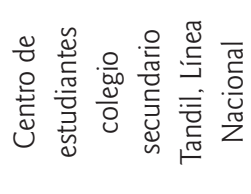 & $\begin{array}{l}\frac{\pi}{0} \\
\frac{\pi}{\sqrt{0}} \\
\frac{0}{a} \\
\bar{a}\end{array}$ & 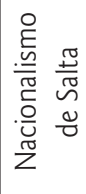 & 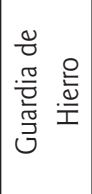 & ' & 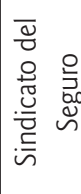 \\
\hline 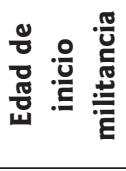 & $\underline{\infty}$ & $\stackrel{\sim}{\sim}$ & $\underline{\underline{n}}$ & 고 & શิ & $\underline{\simeq}$ & $\cong$ & $\underline{\infty}$ \\
\hline 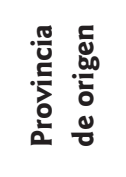 & 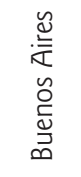 & 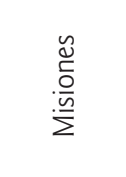 & 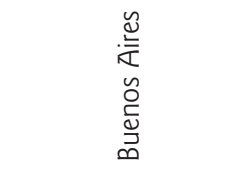 & $\begin{array}{l}\text { N } \\
\frac{N}{0} \\
\frac{D}{N}\end{array}$ & $\frac{\pi}{\sqrt{n}}$ & $\begin{array}{l}\text { N } \\
\frac{0}{0} \\
\frac{D}{0} \\
\sum^{\infty}\end{array}$ & 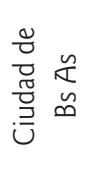 & 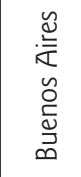 \\
\hline 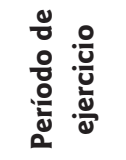 & 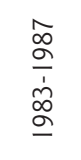 & 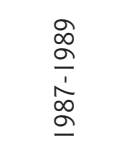 & $\begin{array}{l}\text { ळి } \\
\text { ळ }\end{array}$ & $\begin{array}{l}\text { 心 } \\
\text { ळ }\end{array}$ & $\begin{array}{l}\bar{\sigma} \\
\text { à } \\
\text { ó } \\
\text { ळ }\end{array}$ & $\frac{\text { ू̆ }}{\frac{1}{\sigma}}$ & $\begin{array}{l}\text { ळू } \\
\frac{\alpha}{\dot{\alpha}}\end{array}$ & $\begin{array}{l}\frac{n}{\sigma} \\
\frac{\tilde{\sigma}}{\sigma}\end{array}$ \\
\hline 온 & 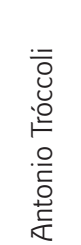 & 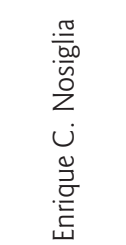 & 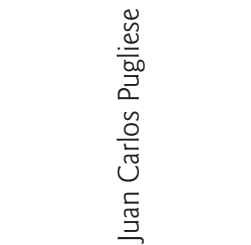 & 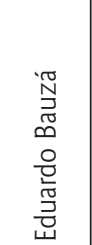 & 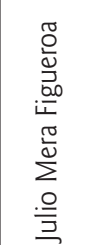 & 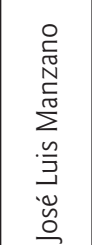 & 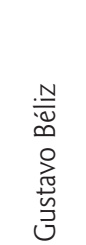 & 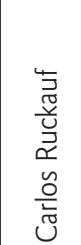 \\
\hline
\end{tabular}




\begin{tabular}{|c|c|c|c|c|c|c|c|}
\hline 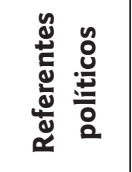 & 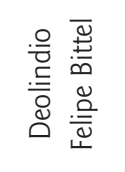 & 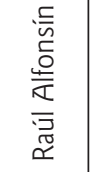 & ' & 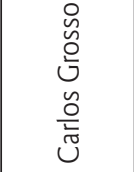 & 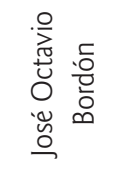 & ' & 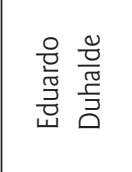 \\
\hline 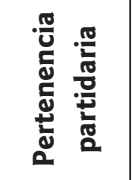 & $\bar{\alpha}$ & $\stackrel{\widetilde{U}}{\sqsupset}$ & 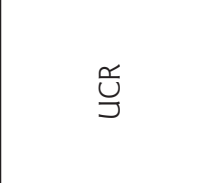 & $\bar{\alpha}$ & $\bar{\alpha}$ & $\bar{\alpha}$ & $\bar{\Sigma}$ \\
\hline 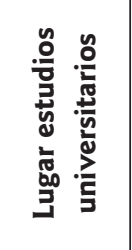 & 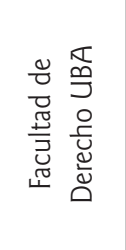 & 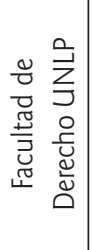 & 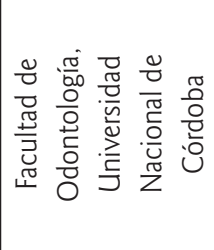 & 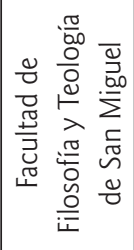 & 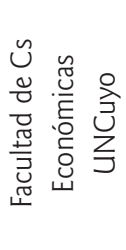 & 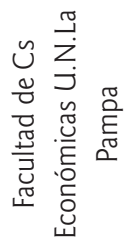 & 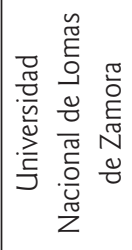 \\
\hline 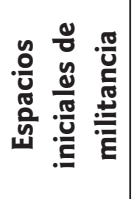 & 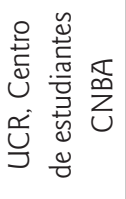 & 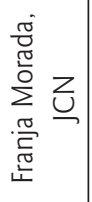 & 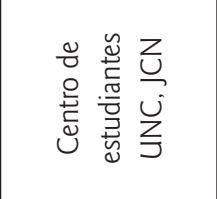 & 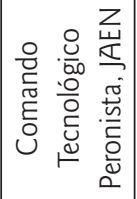 & $\begin{array}{l}\frac{\pi}{N} \\
\frac{O}{0} \\
\frac{D}{\Sigma} \\
\frac{\pi}{2}\end{array}$ & 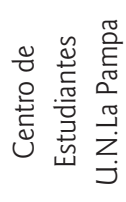 & 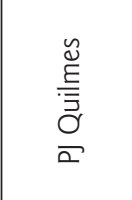 \\
\hline 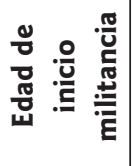 & $\underline{I}$ & $\underline{\simeq}$ & $\underline{-}$ & $\underline{0}$ & $\approx$ & $\underline{0}$ & $\Xi$ \\
\hline 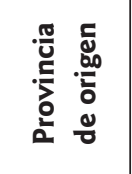 & 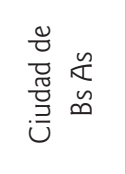 & $\begin{array}{l}\frac{\pi}{0} \\
\frac{0}{0} \\
ن \\
0\end{array}$ & 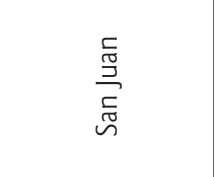 & 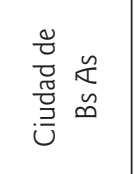 & 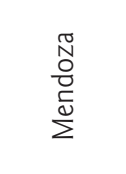 & $\begin{array}{l}\underset{\tilde{Q}}{\tilde{E}} \\
\stackrel{\pi}{\tilde{J}} \\
\widetilde{J}\end{array}$ & 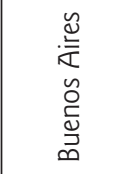 \\
\hline 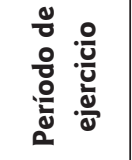 & $\begin{array}{l}\text { ूे } \\
\frac{\text { ลे }}{\text { ล }}\end{array}$ & $\begin{array}{l}\bar{\delta} \\
\text { ஓे } \\
\text { ळे }\end{array}$ & ষ্ণ & ষ্ণ & 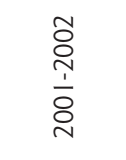 & 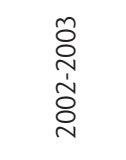 & $\begin{array}{l}\text { } \\
\text { ஸे } \\
\text { ஸे } \\
\text { }\end{array}$ \\
\hline 온 & 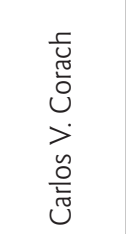 & 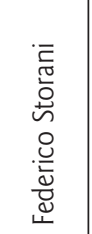 & 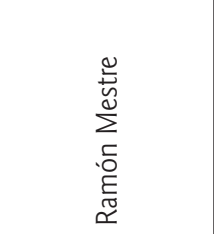 & 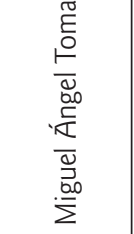 & 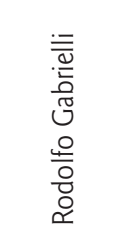 & 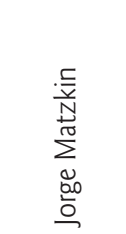 & 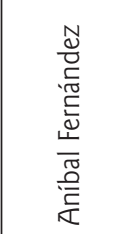 \\
\hline
\end{tabular}


En sintonía con los acontecimientos históricos a los que nos hemos referido, para una parte de los radicales que actuarían en el Ministerio del Interior en los dos períodos en que su partido ocupó el poder a partir de 1983, la militancia comenzó en grupos cercanos al alfonsinismo: la Franja Morada, la Juventud Radical y la Junta Coordinadora Nacional. Frente a la tradición balbinista y conservadora de la Linea Nacional, la irrupción de Raúl Alfonsín desde principios de la década del $70^{20}$ representó un cambio sustantivo y una bocanada de aire fresco en un partido que perdía recursos para interpelar a las masas y a sus propios simpatizantes. Los distintos dirigentes son tajantes en este sentido: desde sus primeros acercamientos, directos o mediados, Alfonsín se presentaba como un líder de características extraordinarias y renovadoras: "Y ¿por qué yo me incorporé? Porque vi en él, aparte de otras características tan interesantes que tenía el propio Raúl, tales como su humanidad etc.; veía en él a un hombre moderno, un hombre distinto a lo que yo habia visto en el marco de la vieja dirigencia. Era un hombre diferente" (Información verbal - GENÉ, 2012) ${ }^{21}$.

Es que yo creo que a pesar de tener tres generaciones de radicales y de tener un diálogo político muy grande con mi padre, eso toda la vida, creo que si no hubiese existido un fenómeno como el alfonsinismo, no me hubiera afiliado al partido, no me hubiera quedado en el radicalismo. Si el radicalismo no hubiera dado una opción como la que ha dado Alfonsín, yo seguramente no hubiera entrado. (Información verbal - Gené, 2012)22.

A tono con los lineamientos de un partido que tradicionalmente recluta sus cuadros políticos en la universidad, muchos de los dirigentes radicales hicieron sus primeros pasos en la Franja Morada. Nacida en 1967, en abierta oposición a la dictadura de Onganía, esta agrupación estudiantil que inicialmente era cercana al radicalismo pero independiente de él, se consolidó pocos años más tarde como la pata universitaria de la UCR, haciéndose particularmente fuerte

20 Entonces diputado de mediana edad, en 1972 Raúl Alfonsín busca desafiar, desde el Movimiento Renovador Nacional, el liderazgo de Ricardo Balbín en la UCR. Sin embargo, en las internas partidarias para definir al candidato presidencial es vencido por la línea balbinista.

21 Subsecretario de Provincias y Secretario de Provincias durante la Presidencia de Alfonsin, UCR. Entrevista con la autora el 27 de mayo de 2009.

22 Viceministro del Interior durante la Presidencia de Alfonsin, UCR. Entrevista con la autora el I de octubre de 2009. 
en Córdoba, Santa Fe, Buenos Aires y la Capital Federal; aunque sus canteras se extendían a todo el país ${ }^{23}$.

En el marco de la Franja Morada se dieron para muchos los primeros aprendizajes prácticos, tales como organizar encuentros y debates, medir fuerzas con otras agrupaciones en jornadas de discusión política y marchas o por medio de elecciones dentro de las facultades. Las competencias para hacer campañas, juntar apoyos, conquistar espacios de todo tipo y negociar lugares en las listas comenzarían a incorporarse desde entonces. El escalafón de la carrera partidaria, tan relevante en el caso del radicalismo que tiene un cursus honorum más marcado que el peronismo, comenzó para muchos en esta rama universitaria. Organizando elecciones, ocupando comisiones en las distintas federaciones universitarias, llegando a la propia presidencia de la Federación Universitaria Argentina (FUA ${ }^{24}$ o abriendo la sección de la Franja Morada en colegios secundarios ${ }^{25}$, esta agrupación propició el escenario para adquirir visibilidad, contactos y recursos válidos ante desafíos políticos.

La Junta Coordinadora Nacional (JCN), en íntima relación con "la Franja"26, constituyó otro de los grandes lineamientos internos que convocaron a múltiples dirigentes radicales. Este grupo, que nació a fines de la década del 60, reunió a jóvenes radicales tras consignas y reivindicaciones de centroizquierda pero en abierta oposición a la lucha armada, que comenzaba a ser una opción para distintos sectores del peronismo y la izquierda (LEUCO; DÍAZ, 1987, p. 65-80). Sus fundadores se acercaron progresivamente a Raúl Alfonsín y participaron de la fundación del Movimiento de Renovación y Cambio - su propia agrupación interna en la UCR - en 1972. Con el tiempo irían separándose en tendencias internas diferenciadas, pero estos inicios serían decisivos para establecer redes de pertenencia y saberes prácticos. Entre los aprendizajes de esos años se encontraron nada más y nada menos que la

23 Por ejemplo, el Secretario de Provincias del Ministerio del Interior durante el gobierno de De la Rúa. Walter Ceballos, comenzó a militar en la Franja Morada de la Provincia de San Luis, en la Facultad de Ingeniería y Ciencias Económicas y Sociales.

24 Es el caso de Federico Storani, que sería ministro del Interior entre 1999 y 2001.

25 Es el caso de Lautaro García Batallán, que sería subsecretario de Interior entre 1999 y 2001 , y Secretario de Asuntos Políticos del Ministerio del Interior en 200I, hasta la caída del gobierno de De la Rúa.

26 Por ejemplo, dos de los fundadores de "la Coordinadora" serían antes presidentes de Franja Morada: Changui Cáceres y Freddy Storani. 
supervivencia y el debate en dictadura, y más tarde el protagonismo en la movilización de la campaña que llevaría a Raúl Alfonsín a la presidencia.

Para los mayores, en cambio, otros espacios servirían de puerta de entrada al mundo de la política en el radicalismo, y más tarde al Ministerio del Interior. El primer ministro político del gobierno de Alfonsín, Antonio Tróccoli, fue un dirigente histórico del partido y uno de los principales referentes de la tradicional Linea Nacional. Su afiliación temprana al radicalismo estuvo marcada por otros eventos históricos y otros contextos de acción del partido. Diputado entre 1963 y 1966, y presidente del bloque radical en la Cámara Baja durante 1973-1976, su cursus honorum se vio interrumpido por sucesivos golpes de Estado, pero esa carrera estaría signada también, al igual que la de Ricardo Balbín, por el fuerte rechazo al peronismo.

Por su parte, en la intrincada madeja de agrupaciones peronistas, harían sus primeros pasos desde temprano muchos de los que unas décadas más tarde ocuparían las primeras y segundas líneas del Ministerio del Interior. Los grupos existentes en ese entonces fueron múltiples, al igual que sus sucesivas divisiones, al calor de las cuales fueron tejiéndose solidaridades y enfrentamientos. Desde la alta politización de fines de la década del 60 hasta la exacerbación de la violencia a mediados de los 70 , los clivajes fueron tensándose y las posiciones dentro del PJ volviéndose cada vez más contradictorias. Muchos de los grupos que en un inicio convivían, debatían y aunaban fuerzas en torno al liderazgo indiscutido del general Perón, terminarían enfrentándose de forma violenta o excluyéndose de modo irreductible. Así, si en un principio la posible vuelta de Perón al país ${ }^{27}$ podía funcionar como una argamasa aglutinante para fracciones muy disímiles del movimiento, más tarde la obediencia o no a su conducción terminaría de sellar las diferencias más tajantes. Para estos grupos en constante y a veces vertiginosa redefinición, que ensamblaban de forma conflictiva tradiciones singularmente diferentes ${ }^{28}$, lo que el peronismo era y lo que debía ser constituían un permanente objeto de disputa.

27 Tras su derrocamiento en 1955, Perón estuvo en el exilio durante 17 años.

28 Sólo a modo de ejemplo, la Tendencia Revolucionaria de Montoneros, cada vez más a la izquierda del peronismo hasta escindirse del lider pasando a la clandestinidad y buscando la revolución por medio de la lucha armada, encontraba en su centro a algunos dirigentes que antes habian formado parte del grupo de extrema derecha y antisemita Tacuara (1955-1965) o que provenían de fracciones católicas de la extrema derecha (GIUSSANI, 1984). 
Para muchos de los dirigentes del ministerio, principalmente durante el gobierno de Menem pero también durante el de Néstor Kirchner, la Facultad de Derecho de la UBA fue un primer punto de encuentro. En efecto, allí se formaron 3 de los 6 ministros menemistas, aunque uno de ellos -Gustavo Béliz - lo haría en los albores de la década del 80, por lo que está ajeno al proceso de politización aquí relatado ${ }^{29}$. La vida universitaria, con un particular epicentro en la principal facultad de Derecho de la Capital Federal, sería un lugar de reunión, conocimiento y aprendizaje político para múltiples grupos militantes que después llegarían a la función pública.

Uno de esos caminos empezaría para muchos en la agrupación JAEN (Juventudes Argentinas para la Emancipación Nacional). Este grupo de fuerte impronta católica y relación con un conjunto de militares que se había opuesto a reprimir durante los sucesos del Cordobazo, era particularmente fuerte en el ámbito universitario. Entre sus principales exponentes se encontraban Rodolfo Galimberti, Carlos Grosso, Chacho Álvarez y Alberto Iribarne ${ }^{30}$. La organización pasaría luego a ser una de las tantas "organizaciones de superficie” de Montoneros, y se fracturaría más tarde, en virtud de discusiones ideológicas y personales, dando lugar en 1970 a una nueva escisión por la que también pasarían muchos funcionarios del ministerio: FORPE (Fuerza para la Organización Revolucionaria Peronista). Esas agrupaciones serían, en efecto, puntos de pasaje para diversos protagonistas de las décadas siguientes, donde se cosecharían vínculos que luego podrían torcerse incontables veces pero que aseguraban, al menos, un conocimiento mutuo y un cierto lenguaje en común. Asimismo, serían el escenario de los primeros aprendizajes y prácticas políticas: largas reuniones de discusión, definición de estrategias y posicionamientos, elaboración de publicaciones y organización de su distribución, movilizaciones, actos y pintadas. Las actividades de este incipiente oficio político incluirían también el trabajo de base y la persuasión

29 Por su parte, Carlos Ruckauf y Carlos Corach terminarian su carrera en la década del 60. El segundo de ellos, formando parte de la Agrupación de Docentes Universitarios Peronistas (ADUP), conoció desde la carrera docente a los distintos grupos que aqui se relevan, y llevaría consigo a muchos de sus cuadros al Ministerio durante su larga gestión en el gobierno menemista.

30 Este último sería una figura clave del Ministerio del Interior tanto en el gobierno de Menem (donde se desempeñaría como viceministro de Corach durante 3 años) como en el de Kirchner (donde ocuparía la Secretaria de Seguridad del ministerio durante 2 años, para pasar luego a revestir como ministro de Justicia). 
de distintos públicos sobre la tarea del peronismo. Por ejemplo, con Perón en el exilio se extendía la práctica de escuchar en grupo sus discursos grabados, pero también la de llevarlos a los barrios y discutirlos casa por casa:

Habia un trabajo barrial de FORPE, que se desarrollaba en Zona Norte, en Vicente López, principalmente en Munro. Había otros trabajos en Capital y en Lanús. Yo participé de sus tareas. La práctica de la época era "timbrear", ir en parejas a visitar las casas en los barrios llevando una cinta de Perón y ofreciamos escucharla y discutirla. Había una gran receptividad de la gente, algunos hasta llegaron a integrarse a la agrupación. ${ }^{31}$.

Otra camada, que más tarde llegaría a la cima del ministerio político, se incorporaría al peronismo desde la denominada "izquierda nacional". Comandados por Abelardo Ramos y otros intelectuales como Rodolfo Puiggrós, diversos universitarios de izquierda se sumarían en los principales centros urbanos del país a este movimiento que reunía en su seno a una mixtura de socialismo, nacionalismo y peronismo. Con la doctrina marxista y la admiración a los caudillos federales, se mezclaban también ciertos componentes sindicales, militares y del catolicismo tercermundista. La formación enciclopédica de la izquierda y de su principal referente se combinaría con la astucia política: en 1973 negociarían con Perón la presentación de una lista alternativa que también lo llevaría al general como candidato a presidente. Bajo la consigna "Vote a Perón desde la izquierda", la boleta presentada por el FIP (Frente de Izquierda Popular) sacó 900.000 votos. No mucho más tarde, este frente de la izquierda nacional terminaría fundiéndose en el justicialismo, pero el grupo significó para muchos el primer espacio de pertenencia y de incorporación de rudimentos políticos: desde debatir ideas y lineamientos estratégicos hasta organizar movilizaciones o armar listas, su formación sería un antecedente potente para su trayectoria política.

Finalmente, otra de las vertientes de la juventud que se incorporaba al peronismo y que después tendría amplia actuación en el Ministerio del Interior sería aquella proveniente del FEN (Frente Estudiantil Nacional). Esta amalgama de organizaciones universitarias, en muchos casos de formación católica, de izquierda o nacionalistas, estaba liderada por Roberto "Pajarito"

31 Entrevista del archivo personal de Alberto Iribarne. Secretario del Interior durante la Presidencia de Menem y Secretario de Seguridad Interior durante la Presidencia de Kirchner, PJ, realizada el 28 agosto 2008. 
Grabois $^{32}$ y se "peronizó" a mediados de la década del 60. Más tarde se unió en la Organización Única de Trasvasamiento Generacional a Guardia de Hierro y, con el amparo de Perón, realizó trabajo territorial en distintos puntos del país (CUCCHETTI, 2007). Defensora de una doctrina "popular y nacional" frente al supuesto carácter "antipopular e internacional" de la izquierda, esta organización mostraba un apego absoluto al pensamiento de Perón y una marcada influencia religiosa (TARRUELA, 2005; CUCCHETI, 2010). La misma sería la cuna de distintos cuadros del menemismo, entre los que se contaba el ministro del Interior José Luis Manzano así como distintas primeras y segundas líneas de la misma cartera.

Años más tarde vendría la clandestinidad de los grupos armados, la escalada de violencia, el desenfreno y el caos tras la muerte de Perón y el gobierno de su viuda que sería interrumpido por la dictadura militar. Para la mayoría de estos dirigentes y militantes, el período 1976-1983 representaría un congelamiento de las actividades políticas y un repliegue sobre las actividades profesionales o trabajos informales en una suerte de exilio interior. Pero esos años transcurridos les habían enseñado un saber-hacer complejo y multifacético, además de haberles otorgado un conjunto relaciones y conocimiento de cuadros con los que después, repetidamente y bajo otros signos, habrían de cruzarse.

Además de estas trayectorias múltiples de militancia juvenil, otras puertas explicarían la llegada al ministerio político tras la vuelta de la democracia. De las tres administraciones peronistas que tuvieron lugar en el período 1983-2007, fue la de Carlos Menem la que absorbió mayor cantidad de estos cuadros en el ministerio del Interior, y en segunda instancia la de Néstor Kirchner. Para muchos otros de los funcionarios, los caminos de aprendizaje político se realizaron en circuitos más locales del interior del país o del Gran Buenos Aires: en la sucesión de cargos públicos en municipios y concejos deliberantes, en la inscripción en sindicatos o grupos profesionales (como los grupos de abogados peronistas que se reunían durante la dictadura), en el acompañamiento de algún líder territorial o el contacto directo con peronistas de la "vieja guardia".

Para los más jóvenes, la inscripción en lineamientos políticos al interior del partido revistió un carácter menos virulento. Ya fuera siguiendo la campańa

32 Funcionario del Ministerio del Interior en distintos cargos entre 1992 y 1999. 
de Menem cuando todavía no había triunfado en las internas, incorporándose a la Renovación peronista y al gobierno de Cafiero en la Provincia de Buenos Aires, o cosechando puestos menores en provincias como Santa Fe, Santa Cruz o los municipios del Conurbano bonaerense, sus ingresos en política también estuvieron marcados por momentos fuertes de la historicidad reciente y grupos de pertenencia que sellaban -aunque de forma precaria - lealtades y prácticas específicas.

En suma, los primeros espacios de militancia constituyen terrenos fuertes de socialización, de constitución de grupos y de incorporación de primeras experiencias. No porque más tarde - ni tan siquiera en los inicios - aquellas redes de pertenencia fueran a mantenerse intactas o las solidaridades selladas de por vida y sin fisuras. Antes bien, porque en esos espacios comenzaron a reconocerse y dominarse las competencias propias del oficio de político en toda su complejidad y dispersión: discutir, persuadir, comunicar; pero también organizar, negociar, demostrar fuerzas. A través de coyunturas y pruebas concretas estos primeros grupos fueron verdaderas usinas de formación política, instancias en las que se iba incorporando un sentido práctico (BOURDIEU, $2007[1980])^{33}$, un saber-hacer que se aprende sobre la marcha y en el que sólo algunos se destacan (y lo hacen, además, en grados disímiles). Muchos de los contactos cultivados en estos años de iniciación podrían activarse más adelante, y aún cuando numerosos caminos se bifurcarían, enfrentando políticamente a los aliados de antaño, esos aprendizajes de la política, sus reglas y sus límites serían potentes en el tiempo.

\section{Padrinos políticos y mentores}

Así como la inscripción en lineamientos internos de los partidos y el papel activo en sus disputas es una de las constantes remarcables de esos primeros ańos, los "padrinos políticos" o mentores juegan un rol importante en la entrada y el mantenimiento en la carrera política. Por un lado, están los referentes más cercanos, aquellos múltiples y variables “otros significantes” (BERGER;

33 O bien, como lo define Giddens en términos muy similares, una conciencia práctica: aquello que "los actores saben (creen) acerca de condiciones sociales, incluidas en especial las condiciones de su propia acción, pero que no pueden expresar discursivamente; sin embargo, ninguna barrera de represión protege a la conciencia práctica, a diferencia de lo que ocurre con lo inconsciente" (GIDDENS, 20II [1984], p. 394). 
LUCKMANN, 2011 [1967]) que tienen mucho que ver con el primer interés y los primeros acercamientos al mundo de la política. Un tío con una profusa biblioteca de izquierda, de historia argentina o de pensamiento nacional y popular en algunos casos; un compañero de secundario o de facultad que transmite la pasión por la militancia o grandes conceptos que despiertan curiosidad en otros. A esos diversos caminos individuales y plurales - en el sentido que le asigna Lahire (2011 [2001]) -, que las entrevistas multiplican y de los que permiten advertir la regularidad, se suma la figura decisiva de los "mentores" o "padrinos".

En muchos casos, se trata de grandes líderes que ejercen una suerte de fascinación sobre quienes se inician, de referentes centrales de un partido o de alguno de sus grupos internos que nuclean en torno a sí a distintos agentes. Por supuesto, hay algo irreductible del carisma en estos personajes, aquella cualidad extraordinaria y extra-cotidiana que suscita la entrega y el reconocimiento de un liderazgo (WEBER, 2005 [1922], p. 193-194) ${ }^{34}$, que explica su capacidad de traccionar voluntades y rodearse de seguidores leales. A su vez, ese carácter de imán y esa capacidad de movilizar se da en distintas escalas, con padrinos que tienen diferentes envergaduras en términos relativos - desde el protagonismo en un municipio hasta la incidencia en la escala nacional; desde la influencia en una parcela del partido hasta la gravitación sobre el conjunto del mismo. Así como el compromiso con la política se inicia o se consolida en muchos casos de su mano, también el acceso a los cargos estará muchas veces estrechamente ligado a su protección y a su relación de cercanía.

Muchos de los ministros del Interior y sus segundas líneas cuentan con este tipo de vínculos, hacia arriba o hacia abajo, o bien en ambos sentidos. En el radicalismo, huelga decirlo nuevamente, Raúl Alfonsín fue un referente casi sin parangón para múltiples dirigentes de primera línea. Dos de los

34 Recordemos la definición de carisma en Weber: se trata de "la cualidad, que pasa por extraordinaria [...], de una personalidad, por cuya virtud se la considera en posesión de fuerzas sobrenaturales o sobrehumanas -o por lo menos especificamente extracotidianas y no asequibles a cualquier otro-, o como enviados del dios, o como ejemplar y, en consecuencia, como jefe, caudillo, guía o líder. El modo como habría de valorarse 'objetivamente' la cualidad en cuestión, sea desde un punto de vista ético, estético u otro cualquiera, es cosa del todo indiferente en lo que atañe a nuestro concepto, pues lo que importa es cómo se valora 'por los dominados' carismáticos, por los 'adeptos'” (WEBER, 2005 [1922], p. 193-194). Por su parte, la validez del carisma reside en el reconocimiento del mismo por parte de los dominados (WEBER, 2005 [1922], p. 194) y en este sentido es ante todo una relación. 
ministros políticos que tuvo este partido en sus distintas gestiones (al final del alfonsinismo, 1987-1989; y desde los inicios de la Alianza, 1999-2001) fueron de su riñón: Enrique "Coti" Nosiglia y Federico Storani. Ambos líderes de la Coordinadora, en las tendencias que marcamos como rivales y en ciertas épocas opuestas, se referencian en su liderazgo y compartieron con él campañas, armados y decisiones íntimas. En el caso particular de Nosiglia, aquella relación fue de extrema confianza y su trama fue constituyéndose desde los albores de la década del 70, cuando Coti era muy joven y Alfonsín disputaba a Balbín la posibilidad de constituir la fórmula presidencial de la UCR en contra de Perón ${ }^{35}$. Más tarde, en la campańa presidencial de 1983 funcionó como su mano derecha y lo acompañó de gira por todo el país, recorriendo pueblos del interior en auto, identificando dirigentes para sumar a sus filas, haciendo las cuentas sobre la capacidad de movilización de la que disponían en cada ámbito. Esta relación, que se parece a lo filial, y en la que cada uno aportaba recursos muy distintos, no estaría exenta de conflictos en el tiempo, pero sería decisiva para ambas partes (GALLO; ÁLVAREZ GUERRERO, 2005, p. 45-57, 106-126).

También una relación de extrema confianza y protección, con visos filiales, fue la que tuvo Carlos Menem con Gustavo Béliz, su cuarto ministro del Interior. Este vínculo comenzó ya en la dictadura, cuando Menem era un caudillo de provincia que se había desempeñado como gobernador de La Rioja hasta 1976 y luego había estado brevemente preso por los militares, y Béliz era un joven estudiante de 19 ańos. El encuentro se produjo por intermedio de un compañero de la facultad de Béliz que en 1981 tenía llegada a Menem por contactos de su padre. Desde entonces, Béliz, que trabajaba como periodista deportivo en El Gráfico, acompañaba a Menem a distintas reuniones, leía con él los diarios y analizaba la coyuntura política. Más tarde, cuando se lanzó la campaña interna del peronismo para dirimir la candidatura presidencial entre Menem y Cafiero, lo acompañó por todos los pueblos del país, y lo mismo hizo en la campaña presidencial de 1989, llegando a ser quien le escribía los discursos. De ambas partes, el vínculo llegó a ser muy estrecho, y se tejió desde temprano, cuando aún muchos de los dirigentes fundamentales del partido apostaban a la Renovación peronista:

35 Quien se impuso en esa oportunidad fue Ricardo Balbin, y se definió la fórmula Balbín-De la Rúa, que obtuvo el 24,4\% de los votos contra la fórmula Perón-Perón en septiembre de 1973. 
Yo era muy joven, calculá que tendría 19 años. Menem era para mi la imagen de un caudillo de provincia, con las patillas por acá; Facundo Quiroga y todo eso... Lo que me impactó siempre de él es que vivía en un departamentito muy humilde en Cochabamba y Jujuy, al cual fui durante muchos años, a las 5, a las 6 de la mañana a leerle los diarios del día [...]. Y a mi me impactó mucho esa cosa de su imagen del interior profundo y esa cosa de mucha austeridad que tenía él en ese momento. Había terminado de estar preso, andaba con lo puesto, era una persona con mucha personalidad. Por supuesto éramos pocos los que estábamos al principio con él, éramos muy poquitos; en un principio él estuvo en la Renovación Peronista, pero luego se enfrenta con Cafiero. Y en la interna con Cafiero, también, él no era el favorito; éramos realmente muy pocos al principio los que estábamos con Menem. (Información verbal - GENÉ, 2012) ) $^{36}$.

Además de estos padrinos que llevarían directamente a cargos de primer orden en el Ejecutivo Nacional, otros funcionaron como iniciadores y transmisores de conocimientos, al tiempo que propiciaron la ocasión de intervenir en negociaciones decisivas y atravesar pruebas de gran relevancia. En este sentido, los dos integrantes de la fórmula presidencial del peronismo que en 1983 fue derrotada frente a Alfonsín, Ítalo Lúder y Leopoldo Bittel, fueron padrinos y mentores de distintos funcionarios del Ministerio del Interior. El propio Carlos Corach - ministro insignia del gobierno de Menem, que ocupó la cartera de Interior durante casi 5 años - fue apadrinado por Bittel, a quien le dedicaría muchos años más tarde su libro de memorias en estos términos: "A Deolindio Felipe Bittel, presidente a cargo del Partido Justicialista entre 1976 y 1983; austero, humilde y valiente, mantuvo la dignidad del justicialismo en los más dramáticos momentos de nuestra historia contemporánea. Enumerar sus incontables enseñanzas y ejemplos sería imposible, basta destacar que de él aprendî" (CORACH, 2011; las cursivas pertenecen al original).

También Alberto Iribarne, que sería viceministro de Carlos Corach entre 1995 y 1997, fue su protegido en estos ańos: junto a Corach eran los encargados de negociar el cierre de listas en nombre de Bittel, con todos los tironeos entre las distintas ramas del peronismo - donde el sindicalismo aún era fuerte - que este acuerdo implicaba. Por su parte, otro de los funcionarios del Ministerio del Interior en el período que recortamos, Gerardo Conte Grand, era uno de los hombres clave de Ítalo Luder, y estuvo a cargo de organizar su campaña en todo el interior del país; así como de ultimar las negociaciones para definir la fórmula presidencial Luder-Bittel cuando la misma todavía estaba en duda.

36 Ministro del Interior durante la Presidencia de Menem, PJ. Entrevista con la autora el 13 julio de 201 I. 
Los ejemplos siguen y en algunos casos son muy ilustrativos de cómo los padrinos pueden influenciar muchas de las decisiones de carrera a futuro, tanto para las derrotas como para los triunfos, tanto para los enfrentamientos y exclusiones como para las solidaridades y las oportunidades de retener espacios a lo largo del tiempo. En todo caso, los padrinos o mentores políticos proveen un encuadramiento, contactos, caminos de ascenso y consolidación; así como también un modo de ver de cerca experiencias del centro del poder. Los primeros éxitos electorales y las primeras derrotas, dos aprendizajes fundamentales de la carrera política, se hacen en muchas ocasiones de la mano de estos referentes o a la sombra de los mismos. Cabe repetirlo una vez más, esa primera entrada no predice el rumbo que habrá de tomarse después: los grandes líderes reclutan, de hecho, seguidores bastante dispares, tanto en sus estilos y modos de hacer política, como en sus posicionamientos ideológicos y en sus competencias distintivas. La cercanía de Alfonsín con Nosiglia y Storani es un buen ejemplo al respecto. Se trata más bien de un proceso continuo y difuso de aprendizaje que podrá activarse en distintos contextos de acción.

Esta entrada a los grandes escenarios de la política de la mano de "padrinos" enseña también otros de los saberes prácticos fundamentales de la política: la importancia relativa de responder a alguien, y, más tarde, de "tener gente", de contar con operadores leales, aquellos que según la jerga de los políticos "son de tal", le responden personalmente, colaboran con su construcción de poder. Tener grandes padrinos es también intervenir en momentos y decisiones importantes. Vivir de cerca situaciones dilemáticas, disyuntivas y negociaciones: cometer errores de apreciación y ver sus resultados; delinear estrategias y constatar sus efectos. He aquí distintos aprendizajes de la profesión política que sólo pueden adquirirse en la práctica. Los padrinos, al igual que los "otros significantes" o los referentes que enseńan a experimentar y definir una forma de apego (BENZECRY, 2012), ofrecen a la vez una posición desde la cual tomar decisiones, sumar experiencias y pasar pruebas, así como una lectura particular de esas situaciones y desafíos, con la cual en muchos casos, se estará en diálogo de forma duradera.

\section{Conclusiones}

Siguiendo la definición de Claude Dubar, entendemos por socialización: 
[...] un proceso biográfico de incorporación de disposiciones sociales producidas no solamente por la familia o la clase de origen, sino por el conjunto de sistemas de acción atravesados por el individuo a lo largo de su existencia. Ella implica por cierto una causalidad histórica del pasado sobre el presente, de la historia vivida sobre las prácticas actuales, pero dicha causalidad es probabilística: excluye toda determinación mecánica de un 'momento' privilegiado sobre los siguientes. (DUBAR, $201 \mathrm{I}$ [200 I]: 75-76).

En este caso, procuramos mostrar tanto la fuerza de los procesos de socialización política ocurridos durante la juventud entre los miembros jerárquicos del ministerio del Interior argentino, como su carácter plural, su no linealidad y la multiplicidad de itinerarios que contribuyeron a incorporar un saber-hacer que sería decisivo en sus trayectorias posteriores.

En primer lugar, mostramos el carácter ineludible de los grandes acontecimientos políticos como fenómenos politizadores durante la segunda mitad del siglo XX. Se trató en Argentina, como en otros países de la región, de un tiempo histórico accidentado, hecho de marchas y contramarchas, de interrupciones recurrentes y violentas del orden constitucional. En ese tiempo sacudido por golpes de Estado, elecciones controladas y proscripciones a fuerzas políticas, harían su entrada amplias camadas de dirigentes. Hasta fines de la década del 70, el clivaje "peronismo-antiperonismo" fue fuerte y contribuyó a sellar una determinada visión de los diferentes partidos en sus participantes, y de lo que ellos representaban en el escenario político argentino. Pero además de la experiencia inicial, esa historia seguiría escribiéndose y sería un objeto de disputa para sus protagonistas, que pugnarían por el sentido de los acontecimientos que los politizaron y se apoyarían, para ello, no sólo en sus vivencias (individuales y colectivas) sino en las lecturas ejemplares que se instalarían de esos episodios tras la vuelta de la democracia.

Lejos de un carácter unívoco, esos hitos de politización proveyeron oportunidades de entrada al mundo de la política, que serían, ellas mismas, plurales. Detenernos en los grupos de militancia iniciales contribuye a mostrar hasta qué punto, bajo el paraguas de un gran momento de politización, anidan experiencias múltiples y disonantes. Un recorrido por los grupos más significativos para quienes ocuparon las primeras y segundas líneas del Ministerio del Interior luego de la recuperación democrática da cuenta de mixturas ideológicas y combinaciones múltiples en esos espacios de pertenencia. Aquellos agrupamientos fueron el marco en que se propiciaron 
distintas lecturas, concepciones de la política, prácticas y estrategias para enfrentar sus desafíos específicos. Los mismos e nutrieron de sectores diversos de la sociedad: grupos de estudiantes secundarios y universitarios, militares, corrientes internas de la Iglesia católica, etc. Las fronteras de esos grupos no serían fijas ni consolidarían solidaridades e identidades necesariamente duraderas entre sus miembros, pero habilitarían redes amplias de lazos débiles (GRANOVETTER, 1973) entre ellos que podrían reactivarse en el futuro.

Finalmente, esas entradas estarían acompañadas en múltiples ocasiones de mentores y padrinos. Aquí nos centramos en aquellos que tienen carácter público, aún cuando las entrevistas permiten reconstruir también a los mentores "anónimos", familiares o amigos cercanos que despiertan intereses o afinidades y promueven caminos de entrada al mundo político. Si nos quedamos con los referentes más conocidos, vemos que los grandes líderes políticos suelen rodearse de diversos seguidores - incluso diversos en lo que a sus competencias y destrezas refiere- y contribuyen a apalancar sus carreras. Por un lado, en el sentido más evidente de que les ofrecen cargos, lugares en listas electorales o espacios en puestos partidarios. Pero además, en un sentido previo y más básico para el oficio de político, que es que les permiten intervenir en múltiples situaciones y escenas de poder, negociar con otros actores en su nombre, conocer la trastienda de decisiones y luchas de fuerza. Es junto a ellos, también, que se aprende una práctica escasamente codificada en términos formales pero que requiere un importante acervo de conocimientos informales y sentido práctico.

\section{Referencias}

ABOY CARLÉS, G. De Malvinas al menemismo. Renovación y contrarrenovación en el peronismo. Sociedad, Buenos Aires, n. 10, p. 5-31, 1996.

ALTAMIRANO, C. "La lucha por la idea": el proyecto de la renovación peronista. In: NOVARO, M.; PALERMO, V. (Comp.). La historia reciente. Argentina en democracia. Buenos Aires: Norma, 2004. p. 59-74.

BENZECRY, C. El fanático de la ópera. Etnografía de una obsesión. Buenos Aires: Siglo XXI, 2012.

BERGER, P.; LUCKMANN, T. [1967]. La construcción social de la realidad. Buenos Aires: Amorrortu, 2011. 
BOURDIEU, P. [1980]. El sentido práctico. Buenos Aires: Siglo XXI, 2007.

CORACH, C. 18.885 días de política. Visiones irreverentes de un país complicado. Buenos Aires: Sudamericana, 2011.

CUCCHETTI, H. Combatientes de Perón, herederos de Cristo. Peronismo, religión secular y organizaciones de cuadros. Buenos Aires, Prometeo, 2010.

De la resistencia peronista al comunitarismo católico: un linaje de conversión católica en trayectorias justicialistas. Nuevo Mundo Mundos Nuevos, [s. p.]. 2007. Disponible en: <http://nuevomundo.revues.org/index3847.html>. Acesso em: 10 ago. 2017.

DE RIZ, L. La política en suspenso, 1966-1976. Buenos Aires: Paidós, 2000.

DUBAR, C. [2001]. La socialisation. Construction des identités sociales et professionnelles. Paris: Armand Colin, 2011.

DUBET, F. Sociologie de l'expérience. Paris: Seuil, 1994.

FERRARI, M. Los políticos en la República radical: prácticas políticas y construcción del poder (1916-1930). Buenos Aires: Siglo XXI, 2008.

GAllO, D.; ÁlvareZ GUERrero, G. El Coti. Biografía no autorizada de Enrique Nosiglia. El dueño de todos los secretos. Buenos Aires: Sudamericana, 2005.

GENÉ, M. Al interior de la política. Trayectorias, destrezas y modos de hacer política en el Ministerio del Interior (1983-2007). 2014. 338 f. Tesis (Doctorado en Sciences Sociales) Ecole des Hautes Etudes en Sciences Sociales, Universidad de Buenos Aires, 2014.

GIDDENS, A. [1984]. La constitución de la sociedad. Bases para la teoría de la estructuración. Buenos Aires: Amorrortu Editores, 2011.

GIUSSANI, P. Montoneros. La soberbia armada. Buenos Aires: Planeta, 1984.

GRANOVETTER, M. The strength of weak ties. American Journal of Sociology, v. 78, n. 6, p. 1360-1380, 1973.

IHL, O. Socialisation et événements politiques. Revue Française de Science Politique, Paris, n. 2-3, p. 125-144, 2002.

LAHIRE, B. L'homme pluriel. Les ressorts de l'action. Paris: Fayard/Pluriel, 2011 (2001).

LÉVÊQUE, S. "L’entrée en politique”. Bibliographie sur les conditions sociales de la professionnalisation et de la "réussite" politique en France. Politix, v. 9, n. 35, p.171-187, 1996. 
LEUCO, A.; DÍAZ, J. A. Los herederos de Alfonsín. Buenos Aires: Sudamericana-Planeta, 1987.

MÉNDEZ, A. El Colegio. La formación de una elite meritocrática en el Nacional Buenos Aires. Buenos Aires: Sudamericana, 2013.

NOVARO, M.; V. PALERMO, V. La dictadura militar 1976-1983. Del golpe de Estado a la restauración democrática. Buenos Aires: Paidós, 2006 (2003).

O’DONNELL, G. [1982]. El Estado burocrático-autoritario. Triunfos, derrotas y crisis. Buenos Aires: Editorial de Belgrano, 1996.

OFFERLÉ, M. Los oficios, la profesión y la vocación de la política. Polhis, n. 7, p. 84-99, 2011.

Les professionalisations politiques en question(s). In: OFFERLÉ, M. (Ed.). La profession politique XIXe-XXIe siècles. Editions Belin/Humensis, 2017. p. 427-498.

OFFERLE, M.; SAWICKI, F. (Ed.) Entrées en politique: apprentissages et savoir-faire. Paris: L'Harmattan, 1996.

ROCK, D. [1977]. El radicalismo argentino. 1890-1930. Buenos Aires: Amorrortu editores, 1992.

ROMERO, J. L. [1956]. Las ideas políticas en Argentina. Buenos Aires: Fondo de Cultura Económica, 1992.

TARRUELA, A. Guardia de Hierro. Buenos Aires: Sudamericana, 2005.

WEBER, M. [1922]. Economía y Sociedad. Esbozo de sociología comprensiva. México DF: Fondo de Cultura Económica, 2005. 


\section{Historical events, groups and mentors: on agents of politicization and multiple ways of entering politics in Argentina}

\section{Abstract}

This article analyzes the processes of politicization of the elites of the Interior Ministry in Argentina. Supported by in-depth interviews, archival material, journalistic records, and specific bibliography, the paper seeks to shed light on the centrality of historical events, militancy groups, and mentors in such paths. Firstly, we reflect on the role of political events understood as milestones of politicization, which then fuel a dispute over their interpretation and appropriation. Then we refer to the multiple character of the militancy groups and the theoretical and practical knowledge there harvested. Finally, we focus on the role played by mentors in facilitating experiences and contacts, fundamental rudiments for the political profession.

Keywords: Political socialization. Historical events. Militancy. Mentors.

Recebido em: 01.06.2017

Aprovado em: 30.08.2017 